\title{
International enzyme units and isoenzyme nomenclature
}

At the present time enzyme activities are expressed in many widely different terms, and comparisons of the activity of two enzymes or of two methods for the same enzyme is often difficult or even impossible. In an attempt to overcome this confusion the Clinical Enzyme SubCommission of the International Union of Biochemistry and the Biological Section of the International Union of Pure and Applied Chemistry has agreed, in conformity with the recommendations contained in the Report of the Commission on Enzymes of the International Union of Biochemistry (1961), to encourage the expression of all activities in terms of international units, defined as micromoles of substrate transformed per minute under defined conditions, preferably optimal. Concentrations are best expressed in units per litre or units per millilitre, depending on which gives the more convenient figure for the particular enzyme. These units are only standard as long as the conditions defining them are strictly adhered to during enzyme assay: if, for example, the temperature of incubation were to change, the apparent activity of the enzyme preparation would also change. It is therefore still essential to specify the method of estimation that has been used.

When alternative assay procedures using different substrates exist for a particular enzyme, e.g., serum alkaline phosphatase, dissimilar values will result, unless the rate of action of the enzyme on each substrate happens to be equal. By expressing activities in international units, a direct comparison can be made of the relative rates at which an enzyme acts on different substrates.

For enzymes such as hyaluronidase, whose activity is not easily expressed in precise chemical terms, an arbitrary standard preparation may be necessary. The activity of certain digestive enzymes cannot readily be converted into micromoles of substrate split or of products formed: the assay of serum amylase by a decrease in the blue colour given by iodine with a starch substrate in a known time is an example of this situation. It is often possible, however, to calibrate such methods against ones in which the reaction can be expressed in international units.

\section{EXAMPLES OF CALCULATIONS FOR THE CONVERSION OF CONVENTIONAL TO INTERNATIONAL UNITS}

AlKaline PhOSPhatase A King-Armstrong unit is defined as the amount of the enzyme that will set free $1 \mathrm{mg}$. of phenol in $15 \mathrm{~min}$. under the conditions of the test, and hence units $=\mathrm{mg}$. of phenol set free by hydrolysis from phenyl phosphate.

Since $1 \mathrm{~K} . A$. unit $=1 \mathrm{mg}$. phenol per $15 \mathrm{~min}$. $=1,000 \mu \mathrm{g}$. phenol per $15 \mathrm{~min}$. $\therefore 1$ K.A. unit $=\frac{1,000}{94} \mu$ moles phenol per $15 \mathrm{~min}$. where 94 is the gram molecular weight of phenol

$$
\begin{aligned}
& =\frac{1,000}{94} \times \frac{1}{15} \mu \text { moles } / \mathrm{min} . \\
& =0.71 \mu \mathrm{moles} / \mathrm{min} .
\end{aligned}
$$

$\therefore 1$ K.A. unit $/ 100 \mathrm{ml}$. (or 10 units $/$ litre) $=7 \cdot 1 \mu \mathrm{moles} /$ min. of alkaline phenylphosphatase activity per litre; and the commonly accepted range of normal values of 3 to 13 K.A. units $/ 100 \mathrm{ml}$. corresponds to about 20 to 90 $\mu$ moles/min./litre.

One Bodansky unit of alkaline phosphatase $=1 \mathrm{mg}$. inorganic $\mathbf{P}$ hydrolysed in one hour from $\beta$-glycerophosphate. Since the atomic weight of $P$ is 31 ,

$$
\begin{aligned}
1 \text { Bodansky unit } & =\frac{1,000}{31} \times \frac{1}{60} \mu \text { moles } / \mathrm{min} . \\
& =0.535 \mu \mathrm{moles} / \mathrm{min} .
\end{aligned}
$$

$\therefore 1$ Bodansky unit $/ 100 \mathrm{ml}$. (or 10 units/litre) $=5.4$ $\mu$ moles $/ \mathrm{min}$. of $\beta$-glycerophosphatase activity per litre; and the normal range of 1 to 5 Bodansky units $/ 100 \mathrm{ml}$. of blood plasma $=5.4$ to 27 international units of $\beta$ glycerophosphatase activity per litre.

PEPTIC ACTIVITY The reaction of proteases with proteins, involving the breaking of large number of bonds within a single molecule, is not readily expressed as micromoles of substrate transformed. Although an acceptable alternative for reactions such as this would be 'equivalent bonds split', their direct measurement would be difficult. Methods for these enzymes usually depend, therefore, on estimation of the amount of a particular reactive group produced. Whilst this value can be expressed in terms of micromoles of product formed, such units do not have the same strict meaning as those obtained for simpler reactions. An example is the method of Anson and Mirsky for peptic activity.

One Anson and Mirsky unit of peptic activity $=1 \mathrm{mg}$. tyrosine hydrolysed in $10 \mathrm{~min}$. from the substrate, haemoglobin. The molecular weight of tyrosine is 181 , so that 1 Anson and Mirsky (A.-M.) unit

$$
\begin{aligned}
& =\frac{1,000}{181} \times \frac{1}{10} \mu \text { moles tyrosine per min. } \\
& =0.55 \mu \text { moles tyrosine per min. }
\end{aligned}
$$

1 A.-M. unit $/ \mathrm{ml}$. $=550 \mu$ moles $/ \mathrm{min}$ of peptic activity (against haemoglobin) per litre.

AMYlaSE The Somogyi method for amylase activity measures the amount of reducing sugar formed by the hydrolytic action of the enzyme on starch. The original unit was defined as that amount of enzyme which produces $1 \mathrm{mg}$. of reducing substances, expressed as glucose, in $30 \mathrm{~min}$. under stated conditions; although this is not 
a true representation of the actual course of the reaction, it can lead to an 'international unit', calculated from the number of micromoles of glucose formed, based on the same assumptions as the Somogyi unit.

1 Somogyi unit $=1 \mathrm{mg}$. glucose produced in $30 \mathrm{~min}$., $=\frac{1,000}{180} \mu$ moles, where 180 is the molecular weight of glucose

i.e., 1 Somogyi unit $=\frac{1,000}{180} \times \frac{1}{30} \mu$ moles per min., $=0.185$ international units or approximately $\mathbf{0 \cdot 2}$ i.u.

The normal range in Somogyi units for the amylase of blood plasma (up to 200 units $/ 100 \mathrm{ml}$.) thus becomes $\frac{200}{5} \times 10=400$ i.u./litre.

Other methods, involving partial degradation of starch, are usually adjusted to give a normal range similar to that of the Somogyi method; the same conversion factor can thus be applied to them.

ISOCITRIC DEHYDROGENASE The method for this enzyme involves the use of N.A.D.P. (T.P.N.) ${ }^{1}$, and the unit is defined as that amount which will produce 1 millimicromole of the reduced form of the coenzyme per hour (Wolfson and Williams-Ashman).

Since $1 \mathrm{~m} \mu \mathrm{mole}=0.001 \mu \mathrm{mole}$

1 Wolfson unit $=0.001 \times \frac{1}{60} \mu \mathrm{mole} / \mathrm{min}$. and since Wolfson units are expressed per $\mathrm{ml}$., they will be equal to

$$
\begin{aligned}
0.001 & \times \frac{1}{60} \times \frac{1,000}{1} \mu \mathrm{moles} / \mathrm{min} . / \text { litre } \\
= & 0.0167 \mu \mathrm{moles} / \mathrm{min} . / \text { litre }
\end{aligned}
$$

The normal range of isocitric dehydrogenase is given by Wolfson and Williams-Ashman as 55 to 225 units, therefore the normal range in $\mu$ moles/min./litre is 0.9 to $3 \cdot 7$.

ENZYMES DETERMINED WITH N.A.D. (D.P.N.) $)^{2}$ Malic dehydrogenase (Wacker et al.), transaminases (Karmen), and lactic dehydrogenase (Wroblewski and LaDue).

One conventional unit $=$ amount of enzyme which will produce a decrease in optical density (O.D.) at 340 $\mathrm{m} \mu$ of $0.001 / \mathrm{min}$. under the conditions described for the method. (Change in O.D. accompanies oxidation of the coenzyme.)

Since $1 \mu$ mole reduced N.A.D./ml. has O.D. of $6 \cdot 3 / \mathrm{cm}$. at $340 \mathrm{~m} \mu$., $1 \mu$ mole in the $3 \mathrm{ml}$. reaction mixture will have O.D. of $2 \cdot 1$.

$$
\begin{aligned}
1 \text { conventional unit } & =\frac{0.001}{2.1} \mu \mathrm{mole} / \mathrm{min} . \\
& =0.00048 \mu \mathrm{mole} / \mathrm{min} . \\
& \text { say, } 0.0005 \mu \mathrm{mole} / \mathrm{min} .
\end{aligned}
$$

$\therefore 1$ conventional enzyme unit $/ \mathrm{ml} .=0.0005 \mu \mathrm{moles} /$ min. $/ \mathrm{ml}$. or $0.5 \mu$ moles $/ \mathrm{min}$./litre.

The commonly accepted normal range of 25 to 100 malic dehydrogenase units/ml. corresponds to 12.5 to 50 $\mu \mathrm{moles} / \mathrm{min}$./litre. The normal range for glutamic oxaloacetic transaminase of 9 to 32 units $/ \mathrm{ml}$. corresponds to $4 \cdot 5-16 \mu \mathrm{moles} / \mathrm{min}$./litre. For glutamic pyruvic transaminase 5-30 units $/ \mathrm{ml}$. corresponds to $2 \cdot 5-15 \mu$ moles/ $\mathrm{min}$./litre. The normal range for lactic dehydrogenase of 100 to 600 units $/ \mathrm{ml}$. corresponds to $50-300 \mu \mathrm{moles} / \mathrm{min}$./ litre.

These examples illustrate how the results of enzyme investigations by existing methods can be rephrased in terms of micromoles per minute. A list of conversion factors of many of the enzymes at present employed for diagnostic purposes is given in the table.

\section{FACTORS FOR CONVERSION OF CONVENTIONAL UNITS TO INTERNATIONAL UNITS PER LITRE} FOR ENZYMES OF CURRENT DIAGNOSTIC SIGNIFICANCE

Enzyme Conventional Units
To obtain umoles/min./litre (international units) Multiply by

\begin{tabular}{llc}
\hline Alkaline phosphatase & King-Armstrong (1 unit/100 ml.) (substrate: phenyl phosphate) & $7 \cdot 1$ \\
& Bodansky (1 unit/100 ml.) (substrate: $\beta$-glycerophosphate) & $5 \cdot 4$ \\
Acid phosphatase & King-Armstrong $(1$ unit/100 ml.) (substrate: phenyl phosphate) & 1.8 \\
& Bodansky (1 unit/100 ml.) (substrate: $\beta$-glycerophosphate) & $5 \cdot 4$ \\
Aldolase & Sibley and Lehninger (1 unit/ml.) & $0 \cdot 75$ \\
Phosphohexose isomerase & Shapira (1 unit/litre) & 16 \\
\end{tabular}

Reactions with N.A.D. (D.P.N.) Transaminases Lactic dehydrogenase Malic dehydrogenase

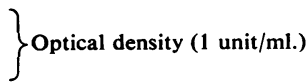

Reactions with N.A.D.P. (T.P.N.) Glutathione reductase Isocitric dehydrogenase

Digestive enzymes

Amylase

Lipase

Somogyi (1 unit/100 ml.)

Peptic activity

The above conversion factors have been rounded-off to facilitate conversion while retaining the degree of significance of the original results.

I Nicotinamide-adenine dinucleotide phosphate (triphosphopyridine nucleotide).

2 Nicotinamide-adenine dinucleotide (diphosphopyridine nucleotide). 
The above conversion factors have been rounded-off to facilitate conversion while retaining the degree of significance of the original results.

NOMENCLATURE OF ISOENZYMES

The discovery that a particular type of enzyme activity may apparently be associated with more than one protein and the diagnostic implications of this finding have resulted in an increasing number of references to these multiple molecular forms of enzymes (variously described as isoenzymes or isozymes) in the literature of chemical pathology. The lactate dehydrogenase (L.D.H.) activity of human tissues, for example, is made up of various proportions of five L.D.H. isoenzymes which are distinguishable by electrophoretic or other means.

In the absence of any officially agreed system of nomenclature, some degree of confusion has arisen in the numbering of these L.D.H. fractions; some workers designate the most rapidly anode-migrating isoenzyme L.D. ${ }_{1}$ and the electrophoretically slowest L.D. ${ }_{5}$, while the reverse convention is followed in other publications. The Standing Committee on Enzymes of the International Union of Biochemistry is now attempting to formulate a standard nomenclature which, it is hoped, will shortly be published. Until its report is available, authors should state clearly which convention of isoenzyme numbering they are following.

References to the methods and units discussed can be found in King, E. J., and Campbell, D. M. (1961). Clin. chim. Acta, 6, 301. Report of Commission on Enzymes of International Union of Biochemistry (1961). Pergamon Press, Oxford.

The suggestions set out above for expressing enzymes in international units and on nomenclature for isoenzymes are recommended and approved by the Technical Methods Committee and the Committee on Chemical Pathology of the Association of Clinical Pathologists.

The late E. J. KING

D. W. MOSS

\section{CORRECTION}

In the Discussion in the paper 'Urea distribution in renal failure' by Blackmore et al. (J. clin. Path., 1963, 16,235 ) the formula on efficiency index in the footnote should read:-

$$
\text { Efficiency index }=100\left[\frac{\mathrm{U}_{\mathrm{c}}-\mathrm{U}_{0}}{\mathrm{U}_{\mathrm{c}}}\right]
$$

\section{Book reviews}

INTERNATIONAL REVIEW OF EXPERIMENTAL PATHOLOGY, Vol. I. Edited by G. W. Richter and M. A. Epstein. (Pp. $\mathrm{x}+$ 453; illustrated. 107s. 6d.) New York and London: Academic Press. 1962.

Despite the current proliferation of scientific periodicals of all types, there has been a remarkable absence of any review, annual or otherwise, devoted to progress in pathology.

This serious aeficiency has now been met by the Academic Press with an International Review of Experimental Pathology which is to appear annually. If the first volume is any guide, the series is likely to prove of the highest value. Volume I contains long articles on antibody production, arteriolar hyalinosis, the electron microscopy of damaged glomeruli, common cold viruses, radiationinduced bone disease, and cellular interactions in histogenesis. All these sections have been prepared with care by recognized authorities working actively in their field, and the standard is extremely high. The book is indeed worth reading from cover to cover and any comparisons between the authors seems uncalled for. The reviewer did, however, particularly enjoy the contributions of Nossal and Tyrrell on antibodies and coryzal viruses respectively. Some chapters, e.g., on electron microscopy, are based entirely on recent observations. In others, e.g., that on arteriolar hyalinosis, the discussion has its basis deep in the roots of pathology, in the controversies between Virchow and Rokitansky. It is this section by Pierre Dustin that reveals how heavily even an apparently well-defined morphological change relies upon experimentation to make it at all comprehensible. Almost everything that we understand, will understand, or think we understand in pathology is based on experimental observations.

The volume is well produced and is warmly recommended to all who have an interest in the study of disease. W. G. SPECTOR

DISEASES OF PORPHYRIN METABOLISM By A. Goldberg and

C. Rimington. (Pp. xvi $+231 ; 38$ figures; 19 plates. 82s. 6d.) Springfield, Illinois: Charles C. Thomas. 1962.

This volume makes a welcome addition to the American Lecture Series. The two authors are both recognized authorities on the subject from their special aspects and the combination of clinical and scientific data has been presented in a most interesting and informative way. The important recent advances which have been made both in the classification and in the biochemistry of the porphyrias makes the book particularly welcome at the present time.

The outlook is unusually wide since chapters are included on subjects such as the history, classification, and geographical distribution of porphyria, and also on experimental and natural porphyria in animals. For the clinician or biochemist the information given on the 